\title{
Importance of the GLUT2 glucose transporter for pancreatic beta cell toxicity of alloxan
}

\author{
M. Elsner ${ }^{1}$, M. Tiedge ${ }^{1}$, B. Guldbakke ${ }^{1}$, R. Munday ${ }^{2}$, S. Lenzen ${ }^{1}$ \\ ${ }^{1}$ Institute of Clinical Biochemistry, Hannover Medical School, Hannover, Germany \\ ${ }^{2}$ AgResearch, Ruakura Agricultural Research Centre, Hamilton, New Zealand
}

\begin{abstract}
Aims/hypothesis. We investigated the importance of the low affinity GLUT2 glucose transporter in the diabetogenic action of alloxan in bioengineered RINm5F insulin-producing cells with different expressions of the transporter.

Methods. GLUT2 glucose transporter expressing RINm5F cells were generated through stable transfection of the rat GLUT2 cDNA under the control of the cytomegalovirus promoter in the pcDNA3 vector. Viability of the cells was determined using a microtitre plate-based 3-[4,5-dimethylthiazol-2-yl]-2,5-diphenyl tetrazolium bromide (MTT) assay.

Results. Cells expressing the GLUT2 transporter were susceptible to alloxan toxicity due to the uptake of alloxan by this specific glucose transporter isoform. The extent of the toxicity of alloxan was dependent upon the GLUT2 protein expression in the cells.

The lipophilic alloxan derivative, butylalloxan, was toxic also to non-transfected control cells. Ex-
\end{abstract}

pression of the GLUT2 glucose transporter caused only a marginal increase in the toxicity of this substance. Butylalloxan, unlike alloxan itself, is not diabetogenic in vivo although, like the latter substance, it is beta-cell toxic in vitro through its ability to generate free radicals during redox cycling with glutathione.

Conclusion/interpretation. Our results are consistent with the central importance of selective uptake of alloxan through the low affinity GLUT2 glucose transporter for the pancreatic beta-cell toxicity and diabetogenicity of this substance. Redox cycling and the subsequent generation of oxygen free radicals leads to necrosis of pancreatic beta cells and thus to a state of insulin-dependent diabetes mellitus, well-known as alloxan diabetes in experimental diabetes research. [Diabetologia (2002) 45:1542-1549]

Keywords Alloxan, butylalloxan, diabetes, RINm5F cells, GLUT2 glucose transporter.
The diabetogenic agent alloxan $[1,2,3,4,5,6,7,8,9]$ is a hydrophilic and chemically unstable pyrimidine derivative [10] which is toxic to pancreatic beta cells because it can generate toxic free oxygen radicals dur-

Received: 15 July 2002 / Published online: 2 October 2002 (C) Springer-Verlag 2002

Corresponding author: Dr. S. Lenzen, Institute of Clinical Biochemistry, Hannover Medical School, D-30623 Hannover, Germany. E-mail: Lenzen.Sigurd@mh-hannover.de

Abbreviations: MTT, 3-[4,5-dimethylthiazol-2-yl]-2,5-diphenyl tetrazolium bromide; DIG, digoxigenin. ing redox cycling in the presence of reducing agents such as glutathione and cysteine $[10,11]$. In contrast to alloxan, lipophilic derivatives such as butylalloxan [12] are not diabetogenic in animals [13] though they are also selectively toxic to pancreatic beta cells in vitro [14]. It has been suggested that alloxan has structural similarities with glucose which might enable this compound to mimic actions of the latter compound when interacting with protein structures in the beta cell which bind glucose [15].

There are two structures in the beta cell which are essential for signal recognition in the process of glucose-induced insulin secretion and which are therefore 
also potential candidates for an interaction with alloxan. These are the low affinity glucose transporter GLUT2 and the low affinity glucose phosphorylating enzyme glucokinase. Inhibition of glucokinase through oxidation of essential SH groups of the enzyme is responsible for the selective inhibition of glucose-induced insulin secretion by alloxan [6]. However, inhibition of glucokinase is not responsible for alloxan-induced beta cell death and is thus not responsible for the development of diabetes in animals treated with this compound [6]. The selective toxicity could be related to the presence of the low affinity glucose transporter GLUT2 in the beta cell plasma membrane. This hypothesis is supported by the observation that the RINm5F rat insulinoma cell line, which does not express this glucose transporter, is resistant to alloxan toxicity [16].

We therefore compared the toxicity of alloxan, using the MTT cytotoxicity assay, in control RINm5F insulin-producing tissue culture cells and in RINm5F cell clones overexpressing the GLUT2 glucose transporter. For comparison we included the lipophilic alloxan derivative butylalloxan which is also selectively beta-cell toxic but is apparently not dependent upon uptake by the low affinity GLUT2 glucose transporter subtype for entering the cell $[12,14]$.

\section{Materials and methods}

Materials. Alloxan monohydrate was obtained from Sigma (St. Louis, Mo., USA). Butylalloxan (N-butylalloxan) was synthesized as described previously [12].

The cDNA coding for the rat GLUT2 glucose transporter and the anti-GLUT2 antibody were kindly provided by B. Thorens (Lausanne, Switzerland). The cDNA for human beta cell glucokinase was kindly provided by A. Permutt (St. Louis, Mo., USA). The glucokinase antibody was generated in rabbits in our laboratory against rat recombinant liver glucokinase [17]. Restriction enzymes were obtained from New England Biolabs (Beverly, Mass., USA), and the SP6/T7 transcription kit and the DIG nucleic acid detection kit from Roche (Mannheim, Germany). Immobilon-P polyvinylidene difluoride (PVDF) membranes were from Millipore (Bedford, Mass., USA). Peroxidase-labelled anti rabbit-IgG antibody and BCA assay reagent were from Sigma. Hybond N nylon membranes, the enhanced chemiluminescence (ECL) detection system, autoradiography films and 3-O-methyl $\left[1-{ }^{3} \mathrm{H}\right]$ glucose were from Amersham (Braunschweig, Germany). Geneticin (G 418), lipofectamine and all other tissue culture equipment were from Invitrogen (Karlsruhe, Germany). Guanidine thiocyanate was from Fluka (Munich, Germany). All other reagents of analytical grade were from Merck (Darmstadt, Germany).

Tissue culture and viability tests. RINm5F insulin-producing tissue culture cells (passage 55-70) were cultured in RPMI 1640 medium, supplemented with $10 \mathrm{mmol} / \mathrm{l}$ glucose, $10 \%$ $(\mathrm{v} / \mathrm{v})$ foetal calf serum, penicillin and streptomycin in a humidified atmosphere at $37{ }^{\circ} \mathrm{C}$ and $5 \% \mathrm{CO}_{2}$ [18]. Control and transfected RINm5F cells were seeded at a density of $2 \times 10^{4}$ cells per well in $100 \mu \mathrm{l}$ culture medium in 96 well microplates, and incubated at $37^{\circ} \mathrm{C}$ with the test compounds. Both test com- pounds were dissolved in $10 \mathrm{mmol} / \mathrm{l} \mathrm{HCl}$ immediately before the experiment and added to Hepes $(20 \mathrm{mmol} / \mathrm{l})$ supplemented KRB medium without glucose for $1 \mathrm{~h}$. The $\mathrm{pH}$ of the buffer was not affected by this addition. The buffer was then removed and the cells were incubated for another $18 \mathrm{~h}$ in RPMI 1640 medium. After the incubation period, the viability of the cells was determined using a microtitre plate-based MTT assay [19] and expressed as a percentage of the untreated samples. Unless otherwise indicated experiments were done in Hepes (20 mmol/l) buffered Krebs-Ringer bicarbonate medium (pH 7.4) [20].

Stable overexpression in RINm5F cells. GLUT2 glucose transporter expressing RINm5F cells were generated through stable transfection of the rat GLUT2 cDNA [21] under the control of the cytomegalovirus promoter in the pcDNA3 vector using lipofectamine as described [22]. Overexpression of glucokinase in RINm5F cells was done in an analogous manner resulting in a tenfold higher enzyme activity [23]. Transfected clones were selected through resistance against G418.

Northern blot analyses. RINm5F cells were homogenised in buffered $4 \mathrm{~mol} / \mathrm{l}$ guanidine thiocyanate solution. Total RNA was isolated according to methods described previously [24]. A total of $10 \mu \mathrm{g}$ RNA per lane were separated through electrophoresis on denaturing formamide-formaldehyde $1 \%$ agarose gels and transferred to nylon membranes. We hybridised RNA using digoxigenin(DIG)-labelled antisense cRNA probes coding for rat GLUT2 glucose transporter [21]. The DIG-labelled hybrids were detected by an enzyme-linked immunoassay followed by chemiluminescence. The intensity of the bands was quantified through computer-based densitometry with the GelPro 3.1 software (Media Cybernetics, Silver Spring, Md., USA).

Western blot analyses. RINm5F cells were homogenised in Krebs-Ringer buffer by sonication on ice $(60 \mathrm{~W}$, three bursts of $10 \mathrm{~s})$. Microsomal protein was prepared according to a previous study [25]. Protein was quantified by a bicinchoninic acid (BCA) assay with bovine albumin as standard. A total of $30 \mu \mathrm{g}$ RINm5F cell protein or microsomal protein were fractionated by reducing $10 \%$ sodium dodecyl sulphate (SDS) polyacrylamide gel electrophoresis and electroblotted to PVDF membranes. The membranes were stained by Ponceau to verify the transfer of comparable amounts of cellular protein. Non-specific binding sites of the membranes were blocked overnight by non-fat dry milk at $4{ }^{\circ} \mathrm{C}$. Thereafter the blots were incubated with specific primary antibody against rat GLUT2 glucose transporter, at a dilution of 1: 10000 overnight at $4{ }^{\circ} \mathrm{C}$, followed by a 2 -h incubation period with peroxidase-labelled secondary antibody at a dilution of 1:15 000 at room temperature. The protein bands were visualised by chemiluminescence using the ECL detection system. The intensity of the bands was also quantified densitometrically.

Glucose transport. RINm5F cells were plated at a density of $3.5 \times 10^{5}$ cells $/ 35 \mathrm{~mm}$ on plastic dishes and grown to confluency within 2 days. Cells were washed twice with Dulbecco's phosphate buffered saline and thereafter incubated twice for 15 min each at $37{ }^{\circ} \mathrm{C}$ with Krebs-Ringer buffer. Cells were then incubated in the absence of glucose for 5 or 60 min with alloxan or butylalloxan. Thereafter, uptake measurements were carried out in the same medium supplemented with $10 \mathrm{mmol} / \mathrm{l}$ 3-O-methyl[1-3 $\left.1{ }^{3}\right]$ glucose $(6 \mu \mathrm{Ci} / \mathrm{ml})$ for 10 to $60 \mathrm{~s}$ and stopped by an excess of ice-cold medium containing $100 \mathrm{mmol} / \mathrm{l}$ glucose thereby preventing efflux of 3-O-methyl $[1-3 \mathrm{H}]$ glucose. Cells were washed five times with this medi- 
um before lysis with $1 \mathrm{ml} 0.5 \%$ sodium dodecyl sulphate. The radioactivity of the lysate was quantified by liquid scintillation counting and results were related to DNA content. Glucose transport of RINm5F cells was quantified as described previously [17]. DNA content of RINm5F cells was determined according to methods described previously [26]. The expression of the GLUT2 glucose transporter protein in the transfected RINm5F cells resulted in an up to 1.7-fold higher 3-OMG uptake compared with non-transfected control cells.

Statistical analyses. Data are expressed as means \pm SEM. Statistical analyses were done using one-way ANOVA followed by Dunnett's test for multiple comparisons. $\mathrm{EC}_{50}$ values were calculated from non-linear regression analyses using one phase experimental association algorithm of the Prism analysis program (Graphpad, San Diego, Calif., USA). A $p$ value of less than 0.05 was considered significant.

\section{Results}

Alloxan toxicity. RINm5F insulin-producing tissue culture cells which do not express the low affinity GLUT2 glucose transporter [18] were resistant to the toxic effect of alloxan (Fig. 1, Table 1). Even at $20 \mathrm{mmol} / \mathrm{l} \mathrm{al}-$ loxan, the highest concentration tested, no decrease in the viability of the cells was recorded (Fig. 1).

The GLUT2 glucose transporter expressing clones GLUT2-A and GLUT2-B and in comparison a glucokinase overexpressing clone and non-transfected RINm5F control cells were exposed to serial concentrations of the test compounds as used in the concentration dependencies shown in Fig. 1. Viability of the cells was determined by the MTT assay. Data are means \pm SEM with the numbers of experiments given in parentheses. The $\mathrm{EC}_{50}$ values were calculated by non-linear regression analyses.

After transfection of the RINm5F cells with the GLUT2 glucose transporter, both clones (A and B) expressing this glucose transporter were sensitive to the toxic action of alloxan as shown by the concentration-dependent loss of cell viability in the MTT assay (Fig. 1).

The half maximally effective concentration $\left(\mathrm{EC}_{50}\right)$ of alloxan, at which $50 \%$ of the cells died, was $9.1 \mathrm{mmol} / \mathrm{l}$ in the GLUT2-A clone and $8.6 \mathrm{mmol} / \mathrm{l}$ in the GLUT2-B clone (Table 1). In both clones, the expression of the GLUT2 glucose transporter was similar to that in rat liver [18].

A further analysis of the relation between the level of GLUT2 glucose transporter protein expression and the toxicity of alloxan in the MTT assay with five clones (A-E) with different levels of GLUT2 glucose transporter expression showed that there was a correlation ( $r=0.91$ ) between the two parameters as evident from the decrease of the $\mathrm{EC}_{50}$ values for alloxan toxicity along with the increase of the GLUT2 glucose transporter protein expression (Table 2).

In contrast, the clone overexpressing glucokinase [18] was no more susceptible to alloxan toxicity than the control cells (Table 1).

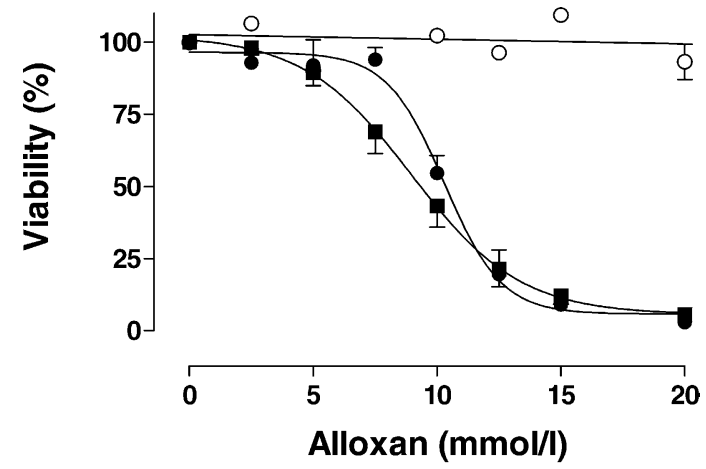

Fig. 1. Effects of GLUT2 glucose transporter expression in insulin-producing RINm5F cells on the toxicity of alloxan in the clones GLUT2-A (O) and GLUT2-B (ם) compared with nontransfected RINm5F control cells $(O)$. Viability was measured by the MTT assay in dependence on the alloxan concentration and expressed as per cent of the untreated cells. Shown are means \pm SEM from four individual experiments

Table 1. Half maximal concentrations $\left(\mathrm{EC}_{50}\right)$ for toxicity in the MTT assay of alloxan and its lipophilic derivative butylalloxan

\begin{tabular}{lll}
\hline $\begin{array}{l}\text { Cell clone } \\
\text { EC }_{50}\end{array}$ & $\begin{array}{l}\text { Alloxan } \\
(\mathrm{mmol} / \mathrm{l})\end{array}$ & $\begin{array}{l}\text { Butylalloxan } \\
(\mathrm{mmol} / \mathrm{l})\end{array}$ \\
\hline RINm5F-control & $\begin{array}{l}\text { No inhibition up to } \\
20 \mathrm{mmol} / \mathrm{l}(4)\end{array}$ & $4.0 \pm 0.4(9)$ \\
& $\begin{array}{l}\text { No inhibition up to } \\
\text { RINm5-GK }\end{array}$ & $4.6 \pm 0.1(6)$ \\
& $20 \mathrm{mmol} / \mathrm{l}(4)$ & $2.3 \pm 0.2(4)^{\mathrm{a}}$ \\
RINm5F-GLUT2-A & $9.1 \pm 0.5(9)^{\mathrm{a}}$ & $2.6 \pm 0.1(11)^{\mathrm{a}}$ \\
\hline
\end{tabular}

${ }^{\mathrm{a}} p<0.01$ compared with non-transfected control RINm5F cells

Butylalloxan toxicity. Control RINm5F cells were sensitive to the toxic effect of the lipophilic alloxan derivative butylalloxan (Fig. 2, Table 1).

After transfection of the RINm5F cells, both clones (A and B) expressing the GLUT2 glucose transporter were more sensitive to the toxic action of butylalloxan as shown by the concentration-dependent loss of cell viability in the MTT assay (Fig. 2). The half maximally effective concentration $\left(\mathrm{EC}_{50}\right)$ of butylalloxan was $2.3 \mathrm{mmol} / \mathrm{l}$ in the GLUT2-A clone and $2.6 \mathrm{mmol} / \mathrm{l}$ in the GLUT2-B clone (Table 1).

There was again a significant correlation $(r=0.90)$ between the $\mathrm{EC}_{50}$ values for butylalloxan and GLUT2 glucose transporter expression level in the five clones (A-E) (Table 2).

Again, as in the case of alloxan, the clone overexpressing glucokinase was not more sensitive towards butylalloxan control RINm5F cells (Table 1).

Glucose protection. Glucose provided a concentrationdependent protection against the toxicity of alloxan (15 $\mathrm{mmol} / \mathrm{l})$ in RINm5F cells overexpressing the GLUT2 glucose transporter (Fig. 3). The concentration of glucose for half maximal protection $\left(\mathrm{EC}_{50}\right)$ 
Table 2 Half maximal concentrations $\left(\mathrm{EC}_{50}\right)$ for toxicity in the MTT assay of alloxan and its lipophilic derivative butylalloxan in six RINm5F cell clones with different levels of GLUT2 glucose transporter protein expression

\begin{tabular}{lccc}
\hline Cell clone & $\begin{array}{l}\text { GLUT2 expression } \\
\%\end{array}$ & $\begin{array}{l}\text { Alloxan } \\
\mathrm{EC}_{50}(\mathrm{mmol} / \mathrm{l})\end{array}$ & $\begin{array}{l}\text { Butylalloxan } \\
\mathrm{EC}_{50}(\mathrm{mmol} / \mathrm{l})\end{array}$ \\
\hline RINm5F-control & not detectable $(4)$ & No inhibition up to $20 \mathrm{mmol} / \mathrm{l}(4)$ & $4.0 \pm 0.3(9)$ \\
RINm5F-GLUT2-E & $28.7 \pm 3.1(4)$ & $22 \pm 1.5(10)$ & $3.6 \pm 0.3(6)$ \\
RINm5F-GLUT2-D & $39.1 \pm 2.7(4)$ & $20 \pm 1.2(5)$ & $2.7 \pm 0.2(4)$ \\
RINm5F-GLUT2-A & $52.1 \pm 2.9(4)$ & $9.1 \pm 0.5(9)$ & $2.3 \pm 0.2(4)$ \\
RINm5F-GLUT2-B & $77.3 \pm 2.7(4)$ & $8.6 \pm 0.5(10)$ & $2.6 \pm 0.1(11)$ \\
RINm5F-GLUT2-C & $100.0 \pm 0.0(4)$ & $4.4 \pm 0.4(5)$ & $1.9 \pm 0.3(4)$ \\
\hline
\end{tabular}

$\%$ of expression of the clone $\mathrm{C}$ with the highest expression $(100 \%)$. There was a correlation $(p<0.01)$ with correlation coefficients of $r=0.91$ between the level of GLUT2 protein ex-

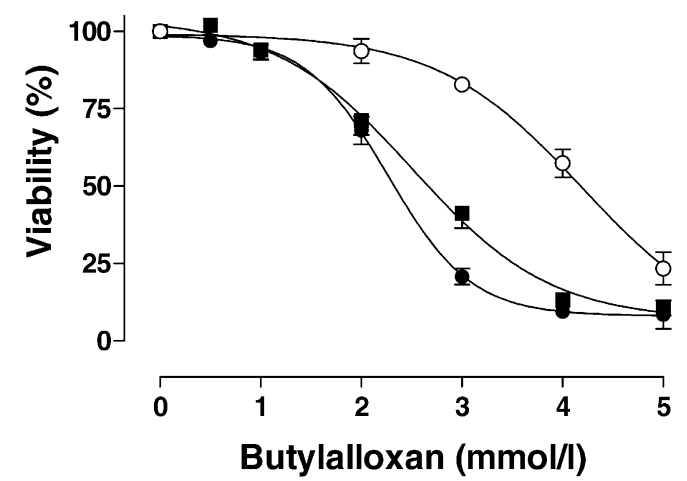

Fig. 2. Effects of GLUT2 glucose transporter expression in insulin-producing RINm5F cells on the toxicity of butylalloxan in the clones GLUT2-A (O) and GLUT2-B (ם) compared with non-transfected RINm5F control cells $(\bigcirc)$. Viability was measured by the MTT assay in dependence on the butylalloxan concentration and expressed as per cent of the untreated cells. Shown are means \pm SEM from four individual experiments

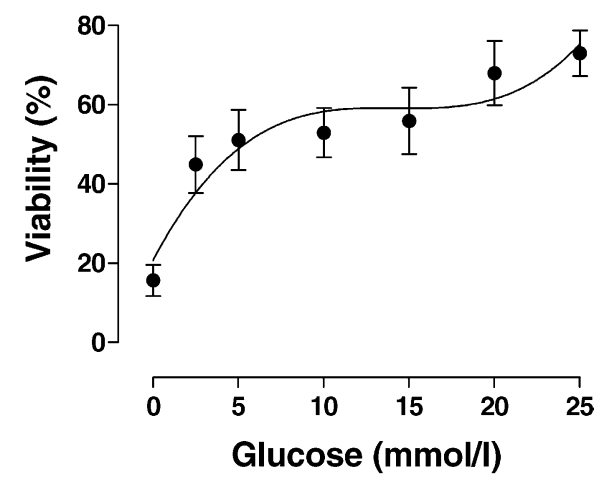

Fig. 3. Concentration-dependent protection of glucose against the toxicity of alloxan $(15 \mathrm{mmol} / \mathrm{l})$ in GLUT2 glucose transporter expressing RINm5F cell clone GLUT2-A. Viability was measured by the MTT assay in dependence on the alloxan concentration and expressed as per cent of the untreated cells. Shown are means \pm SEM from four individual experiments

against alloxan toxicity was $11.3 \pm 3.0 \mathrm{mmol} / \mathrm{l}(n=5)$ in the GLUT2-A clone. This was confirmed in the GLUT2-B clone with a value of $14.8 \pm 3.5 \mathrm{mmol} / \mathrm{l}$ $(n=5)$. pression and both the increase of the $\mathrm{EC}_{50}$ values for the toxicity of alloxan and butylalloxan

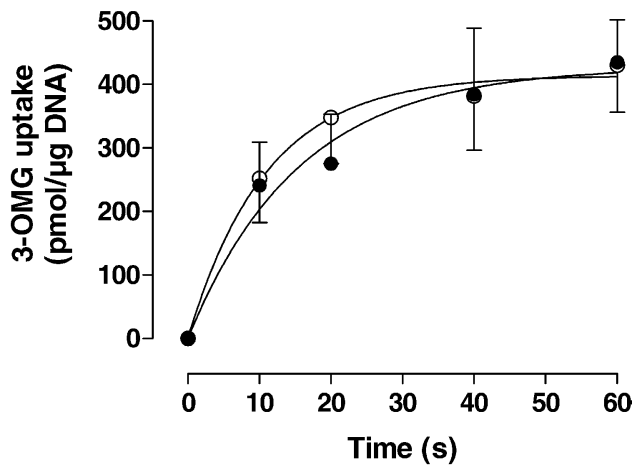

Fig. 4. Lack of effect of alloxan $(15 \mathrm{mmol} / \mathrm{l})$ on 3-O-methyl[1-3 $\left.{ }^{3} \mathrm{H}\right]$ glucose $(3-\mathrm{OMG})(10 \mathrm{mmol} / \mathrm{l})(6 \mu \mathrm{Ci} / \mathrm{ml})$ uptake by non-transfected RINm5F cells. $15 \mathrm{mmol} / \mathrm{l}$ alloxan $(\bullet)$, no alloxan $(\bigcirc)$. Shown are means \pm SEM from four individual experiments

Glucose provided protection also against the toxicity of butylalloxan ( 5 or $3 \mathrm{mmol} / \mathrm{l})$. This protection was evident in RINm5F control cells and in the GLUT2 glucose transporter expressing RINm5F cells. The concentrations of glucose for half maximal protection $\left(\mathrm{EC}_{50}\right)$ against butylalloxan toxicity were $0.4 \pm 0.1 \mathrm{mmol} / \mathrm{l} \quad(n=4)$ in the control cells and $0.3 \pm 0.1 \mathrm{mmol} / \mathrm{l}(n=7)$ in the GLUT2-A clone.

Glucose transport. Alloxan at a concentration of $15 \mathrm{mmol} / \mathrm{l}$ did not affect the uptake of 3-O-methyl[1$\left.{ }^{3} \mathrm{H}\right]$ glucose $(10 \mathrm{mmol} / \mathrm{l})$ in control RINm5F cells (Fig. 4) or in cells overexpressing glucokinase.

In cells expressing the GLUT2 glucose transporter, however, the uptake of 3-O-methyl[1-3 $\mathrm{H}]$ glucose was inhibited after incubation with $15 \mathrm{mmol} / \mathrm{l}$ alloxan for 60 min (A-clone, Fig. 5; B-clone, curve not shown). The reduction of the uptake rate was calculated to be $47.2 \pm 4.1 \%(n=4)$ in the A clone and $36.6 \pm 6.4 \%(n=4)$ in the $\mathrm{B}$ clone. When the 3-O-methyl[1-3 $\mathrm{H}]$ glucose $(10 \mathrm{mmol} / \mathrm{l})$ uptake experiments were done only $5 \mathrm{~min}$ after alloxan was added to the cells, the reduction of the uptake rate was $10.2 \pm 3.4 \%(n=4)$ in the case of the 


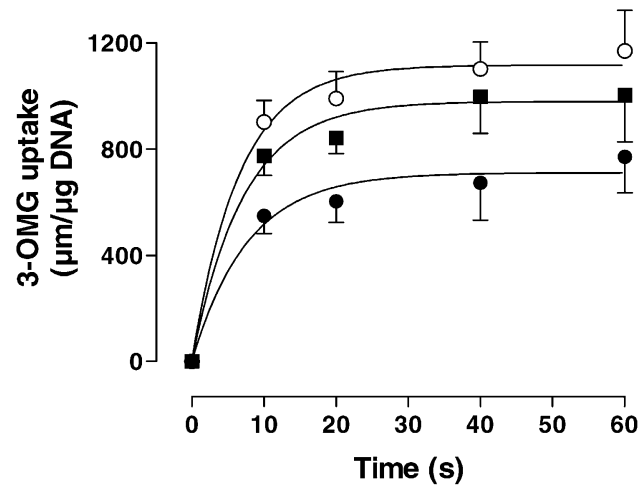

Fig. 5. Effects of alloxan (15 mmol/l) on 3-O-methyl[1${ }^{3} \mathrm{H}$ ]glucose $(3-\mathrm{OMG})(10 \mathrm{mmol} / \mathrm{l})(6 \mu \mathrm{Ci} / \mathrm{ml})$ uptake by the GLUT2 glucose transporter expressing RINm5F cell clone GLUT2-A and the protective effect of glucose $(25 \mathrm{mmol} / \mathrm{l})$. $15 \mathrm{mmol} / \mathrm{l}$ alloxan $(\mathbf{O})$, no alloxan $(\bigcirc), 15 \mathrm{mmol} / \mathrm{l}$ alloxan + $25 \mathrm{mmol} / \mathrm{l}$ glucose $(\boldsymbol{\square})$. Shown are means \pm SEM from four individual experiments

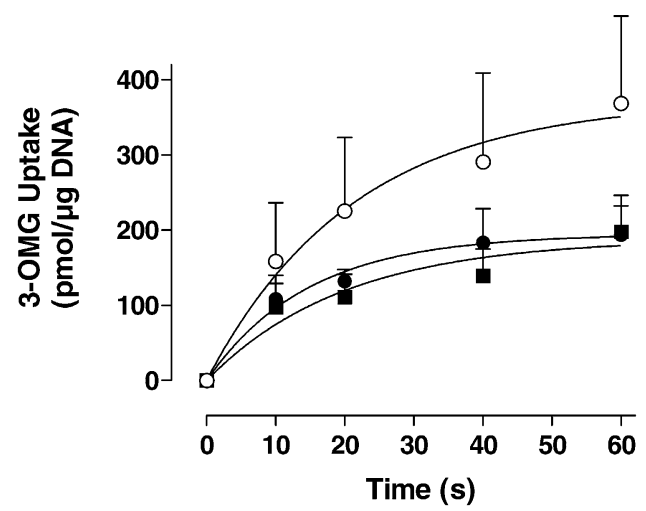

Fig. 6. Effects of butylalloxan $(5 \mathrm{mmol} / \mathrm{l})$ on 3-O-methyl[1$\left.{ }^{3} \mathrm{H}\right]$ glucose $(3-\mathrm{OMG})(10 \mathrm{mmol} / \mathrm{l})(6 \mu \mathrm{Ci} / \mathrm{ml})$ uptake by nontransfected RINm5F cells and the lack of a protective effect of glucose ( $25 \mathrm{mmol} / \mathrm{l}) .5 \mathrm{mmol} / \mathrm{l}$ butylalloxan $(\mathbf{)})$, no butylalloxan $(\bigcirc), 5 \mathrm{mmol} / \mathrm{l}$ butylalloxan $+25 \mathrm{mmol} / \mathrm{l}$ glucose $(\boldsymbol{\square})$. Shown are means \pm SEM from four individual experiments

A clone and $13.9 \pm 3.5 \%(n=4)$ in the case of the B clone. Glucose $(25 \mathrm{mmol} / \mathrm{l})$ provided protection against this inhibitory effect of alloxan upon 3-Omethyl $\left[1-{ }^{3} \mathrm{H}\right]$ glucose uptake (Fig. 5).

Butylalloxan $(5 \mathrm{mmol} / \mathrm{l}), 60 \mathrm{~min}$ after the cells were added, also inhibited glucose transport. However, inhibition was evident both in the RINm5F control cells (Fig. 6) and in the GLUT2 glucose transporter expressing RINm5F cells (Fig. 7), as shown by a reduction of 3-O-methyl[1-3 $\mathrm{H}]$ glucose $(10 \mathrm{mmol} / \mathrm{l})$ uptake of $47.8 \pm 4.2 \%(n=4)$ in the control cells and $56.5 \pm 2.7 \%(n=4)$ in the A clone of the GLUT2 glucose transporter expressing RINm5F cells.

When the 3-O-methyl $\left[1-{ }^{3} \mathrm{H}\right]$ glucose $(10 \mathrm{mmol} / \mathrm{l})$ uptake experiments were done only 5 min after butylalloxan was added to the cells, the reduction of the uptake rate was $16.3 \pm 2.7 \%(n=4)$ in the control cells and $19.8 \pm 3.5 \%(n=4)$ in the A clone of the GLUT2 glu-

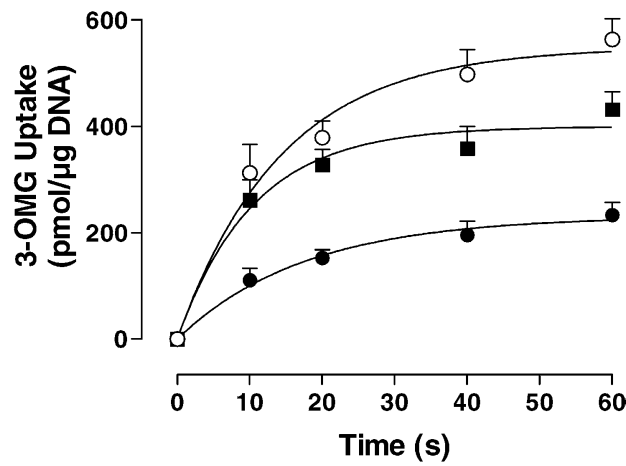

Fig. 7. Effects of butylalloxan $(3 \mathrm{mmol} / \mathrm{l})$ on 3-O-methyl[1${ }^{3} \mathrm{H}$ ]glucose $(3-\mathrm{OMG})(10 \mathrm{mmol} / \mathrm{l})(6 \mu \mathrm{Ci} / \mathrm{ml})$ uptake by the glucose transporter expressing RINm5F cell clone GLUT2-A and the protective effect of glucose $(25 \mathrm{mmol} / \mathrm{l}) .3 \mathrm{mmol} / \mathrm{l} \mathrm{bu}-$ tylalloxan (๑), no butylalloxan $(\bigcirc), 3 \mathrm{mmol} / \mathrm{l}$ butylalloxan + $25 \mathrm{mmol} / \mathrm{l}$ glucose (ם). Shown are means \pm SEM from four individual experiments

cose transporter expressing RINm5F cells. Glucose $(25 \mathrm{mmol} / \mathrm{l})$ protected against the inhibitory effect of butylalloxan upon 3-O-methyl $\left[1-{ }^{3} \mathrm{H}\right]$ glucose (10 mmol/l) uptake in GLUT2 glucose transporter expressing RINm5F cells (Fig. 7) but not in RINm5F control cells (Fig. 6).

\section{Discussion}

To elucidate the mechanism underlying the selective beta-cell toxic action of the diabetogen alloxan, we adopted a combined approach comprising the engineering of insulin-producing cells with different expression levels of the GLUT2 glucose transporter and the use of butylalloxan, a lipophilic derivative of alloxan. Butylalloxan was especially synthesized as a tool, as this alloxan derivative is not dependent on the low affinity GLUT2 glucose transporter for entering the cell.

Our results, together with previous observations, explain the mechanism of the beta-cell toxic and diabetogenic action of alloxan as follows:(i)

(i) The toxic action of alloxan requires uptake into the cell.

(ii) Alloxan is a diabetogenic compound causing beta-cell death due to its ability to be taken up selectively by beta cells $[27,28]$ using the low affinity GLUT2 glucose transporter.

(iii) The steric similarity of alloxan with the glucose molecule [15] enables alloxan to be transported into the beta cell through this specific low affinity glucose transporter. The GLUT2 glucose transporter substrate glucose protects against the toxicity of alloxan with a half maximal protective concentration in the range of the millimolar $\mathrm{K}_{\mathrm{m}}$ of this low affinity glucose transporter sub- 
type. Glucose protection is apparently the result of a competition between the glucose molecule and the alloxan molecule for the glucose transporter rather than due to a metabolic effect [29].

(iv) In insulin-producing cells not expressing the GLUT2 glucose transporter, cellular uptake of alloxan is very low [30] and toxicity to these cells is therefore not detectable in the MTT cytotoxicity assay, at least at concentrations up to $20 \mathrm{mmol} / \mathrm{l}$ as used in our study. This also shows that the high affinity GLUT1 glucose transporter, which is expressed in the RINm5F insulin-producing cells [31], is not central for the transport of alloxan into the cell.

(v) The toxic action of butylalloxan is also dependent upon uptake into the cell. But due to the lipophilic character of this derivative [12], in contrast to the hydrophilic alloxan, it is apparently taken up into the cell also via the high affinity GLUT1 glucose transporter. Glucose protects against the toxicity of alloxan with a half maximal protective concentration in the range of the $\mathrm{K}_{\mathrm{m}}$ of the this high affinity glucose transporter subtype. Therefore, butylalloxan is toxic also to insulin-producing cells not expressing the GLUT2 glucose transporter. As virtually all cell types express the GLUT1 glucose transporter, it is not surprising that butylalloxan is acutely and systemically toxic rather than diabetogenic in rats [13].

(vi) The additional expression of the GLUT2 glucose transporter increased the toxicity of butylalloxan, because the additional presence of this low affinity glucose transporter isoform allowed additional uptake of the toxin into the cells.

(vii) The importance of the GLUT2 transporter as the pathway for alloxan uptake into the cell is also supported by the observation that alloxan damages other cells which, like beta cells, express this transporter. These include hepatocytes and renal tubular cells [21], and alloxan given to animals leads to diabetes and can cause liver and kidney damage [3].

(viii) Glucokinase, the low affinity glucose phosphorylating enzyme and glucose sensor of the pancreatic beta cell, which together with the GLUT2 transporter, is responsible for generating the signal for glucose-induced insulin secretion [32, 33, $34,35]$ is not responsible for the beta-cell toxic action of alloxan. Nevertheless, inhibition of glucokinase $[36,37,38]$ is responsible for selective inhibition of glucose-induced insulin secretion by alloxan [6].

(ix) Alloxan $[10,11]$ and lipophilic derivatives such as butylalloxan [12] are toxic because they generate toxic oxygen free radicals. These oxygen free radicals generated along a defined chain of events during rapid redox cycling between dial- uric acid and alloxan [10, 11, 12, 39] cause necrosis of the beta cells $[4,8,14]$.

(x) Alloxan and butylalloxan, at $\mathrm{pH} 7.4$ and at $37^{\circ} \mathrm{C}$, have a half life of only $1.5 \mathrm{~min}[10,12]$. Thus, under physiological conditions, more than $90 \%$ of the test compounds are decomposed within 5 min of incubation in physiological media. Since the decomposition products are not toxic to beta cells [6], uptake of the compounds into the cell must be completed within 5 min to show its beta-cell toxic action. Though both alloxan and butylalloxan can reduce the rate of glucose uptake into the cells, this effect is negligibly small within the first $5 \mathrm{~min}$ of exposition exposure of the cells to the test compounds as shown in the glucose uptake experiments in this study. This effect, which could be due to an oxidation of $\mathrm{SH}$ groups in the glucose transporter protein, does not contribute to the diabetogenic effect of alloxan. The decrease of GLUT2 mediated glucose transport $1 \mathrm{~h}$ after alloxan exposure indicates that damage of beta-cell proteins results in a progressive deterioration of beta-cell function which ultimately leads to beta-cell death as a sum of oxidative events.

In conclusion, it is possible to explain the mechanism underlying the selective necrotic pancreatic beta-cell destruction in alloxan diabetes, one of the most popular models of chemically-induced insulin-dependent diabetes mellitus in animals. It is the selective uptake of the drug through the low affinity GLUT2 glucose transporter into the beta cell that leads to the destruction of the transporter protein through oxygen free radical mediated damage [40]. In chemical terms it is the steric similarity of the alloxan molecule to that of the glucose molecule [15] which confers preferential uptake of alloxan into the beta cell $[27,28]$, while it is the generation of oxygen free radicals which is responsible for the selective necrosis of the beta cell.

Subpopulations of insulin-producing cells with higher resistance towards toxicity of alloxan and streptozotocin, selected through repeated exposure to these toxins, showed decreased GLUT2 glucose transporter expression [41]. This corresponds with our results for alloxan and in other studies for streptozotocin $[18,42]$. However, in such studies it is not possible to exclude other reasons for increased resistance against toxicity such as an improved antioxidative defence status $[43,44]$.

Acknowledgements. Some of the results were obtained from the thesis work by B. Guldbakke. On the occasion of the $60^{\text {th }}$ anniversary of the first description of alloxan diabetes, this publication is dedicated to Dr. Norman G. B. McLetchie, the co-discoverer of the diabetogenic action of alloxan. 


\section{References}

1. Dunn JS, Sheehan HL, McLetchie NGB (1943) Necrosis of islets of Langerhans produced experimentally. Lancet i: 484-487

2. Dunn JS (1943) An experimental lesion of the pancreatic islets. Surgo 9: 32-34

3. Rerup CC (1970) Drugs producing diabetes through damage of the insulin secreting cells. Pharmacol Rev 22: 485-518

4. Malaisse WJ (1982) Alloxan toxicity to the pancreatic Bcell. A new hypothesis. Biochem Pharmacol 31: 3527-3534

5. McLetchie NGB (1982) Alloxan Diabetes: The scorer and his apprentice. Diabetologia 23: 72-75

6. Lenzen S, Panten U (1988) Alloxan: history and mechanism of action. Diabetologia 31: 337-342

7. Lenzen S, Tiedge M, Jörns A, Munday R (1996) Alloxan derivatives as a tool for the elucidation of the mechanism of the diabetogenic action of alloxan. In: Shafrir E (ed) Lessons from Animal Diabetes,Birkhäuser, Boston, pp 113-122

8. Okamoto H (1996) Okamoto model for B-cell damage: recent advances. In: Shafrir E (ed) Lessons from animal diabetes,Birkhäuser, Boston, pp 97-111

9. Szkudelski T (2001) The mechanism of alloxan and streptozotocin action in B cells of the rat pancreas. Physiol Res 50: 537-546

10. Lenzen S, Munday R (1991) Thiol-group reactivity, hydrophilicity and stability of alloxan, its reduction products and its N-methyl derivatives and a comparison with ninhydrin. Biochem Pharmacol 42: 1385-1391

11. Munday R (1988) Dialuric acid autoxidation. Effects of transition metals on the reaction rate and on the generation of "active oxygen" species. Biochem Pharmacol 37: 409-413

12. Munday R, Ludwig K, Lenzen S (1993) The relationship between the physicochemical properties and the biological effects of alloxan and several $\mathrm{N}$-alkyl substituted alloxan derivatives. J Endocrinol 139: 153-163

13. Brückmann G, Wertheimer E (1947) Alloxan studies: The action of alloxan homologues and related compounds. J Biol Chem 168: 241-256

14. Jörns A, Munday R, Tiedge M, Lenzen S (1997) Comparative toxicity of alloxan, $\mathrm{N}$-alkylalloxans and ninhydrin to isolated pancreatic islets in vitro. $\mathrm{J}$ Endocrinol 155: 283-293

15. McDaniel ML, Bry CG, Fink CJ, Homer RW, Lacy PE (1979) Studies on the site of interaction for ninhydrin, alloxan, and D- glucose in insulin secretion by isolated islets in vitro. Endocrinology 105: 1446-1451

16. Flatt PR, Swanston-Flatt SK, Tan KS, Marks V (1987) Effects of cytotoxic drugs and inhibitors of insulin secretion on a serially transplantable rat insulinoma and cultured rat insulinoma cells. Gen Pharmacol 18: 293-297

17. Tiedge M, Richter T, Lenzen S (2000) Importance of cysteine residues for the stability and catalytic activity of human pancreatic beta cell glucokinase. Arch Biochem Biophys 375: 251-260

18. Elsner M, Guldbakke B, Tiedge M, Munday R, Lenzen S (2000) Relative importance of transport and alkylation for pancreatic beta- cell toxicity of streptozotocin. Diabetologia 43: 1528-1533

19. Korting HC, Schindler S, Hartinger A, Kerscher M, Angerpointner T, Maibach HI (1994) MTT-assay and neutral red release (NRR)-assay: relative role in the prediction of the irritancy potential of surfactants. Life Sci 55: 533-540

20. Lenzen S (1979) Insulin secretion by isolated perfused rat and mouse pancreas. Am J Physiol 236: E391-E400
21. Thorens B, Sarkar HK, Kaback HR, Lodish HF (1988) Cloning and functional expression in bacteria of a novel glucose transporter present in liver, intestine, kidney, and beta-pancreatic islet cells. Cell 55: 281-290

22. Tiedge M, Lortz S, Drinkgern J, Lenzen S (1997) Relation between antioxidant enzyme gene expression and antioxidative defense status of insulin-producing cells. Diabetes 46: 1733-1742

23. Tiedge M, Elsner M, McClenaghan NH et al. (2000) Engineering of a glucose-responsive surrogate cell for insulin replacement therapy of experimental insulin-dependent diabetes. Hum Gene Ther 11: 403-414

24. Chomczynski P, Sacchi N (1987) Single-step method of RNA isolation by acid guanidinium thiocyanate- phenolchloroform extraction. Anal Biochem 162: 156-169

25. Weiser MM (1973) Intestinal epithelial cell surface membrane glycoprotein synthesis. I. An indicator of cellular differentiation. J Biol Chem 248: 2536-2541

26. Rago R, Mitchen J, Wilding G (1990) DNA fluorometric assay in 96-well tissue culture plates using Hoechst 33258 after cell lysis by freezing in distilled water. Anal Biochem 191: 31-34

27. Weaver DC, McDaniel ML, Lacy PE (1978) Alloxan uptake by isolated rat islets of Langerhans. Endocrinology 102: $1847-1855$

28. Malaisse WJ, Doherty M, Ladriere L, Malaisse-Lagae F (2001) Pancreatic uptake of [2-(14)C]alloxan. Int J Mol Med 7: 311-315

29. Malaisse-Lagae F, Sener A, Malaisse WJ (1983) Contrasting modes of action of D-glucose and 3-O-methyl-D-glucose as protectors of the rat pancreatic B-cell against alloxan. Biochim Biophys Acta 762: 36-43

30. De Vos A, Heimberg H, Quartier E, Huypens P, Bouwens L, Pipeleers D, Schuit F (1995) Human and rat beta cells differ in glucose transporter but not in glucokinase gene expression. J Clin Invest 96: 2489-2495

31. Tiedge M, Hohne M, Lenzen S (1993) Insulin secretion,insulin content and glucose phosphorylation in RINm5F insulinoma cells after transfection with human GLUT2 glucose- transporter cDNA. Biochem J 296: 113-118

32. Meglasson MD, Matschinsky FM (1986) Pancreatic islet glucose metabolism and regulation of insulin secretion. Diabetes Metab Rev 2: 163-214

33. Lenzen S, Panten U (1988) Signal recognition by pancreatic B-cells. Biochem Pharmacol 37: 371-378

34. Matschinsky FM (1990) Glucokinase as glucose sensor and metabolic signal generator in pancreatic beta-cells and hepatocytes. Diabetes 39: 647-652

35. Matschinsky FM (1996) Banting Lecture 1995. A lesson in metabolic regulation inspired by the glucokinase glucose sensor paradigm. Diabetes 45: 223-241

36. Miwa I, Hara H, Matsunaga H, Okuda J (1984) Inhibition of glucokinase in hepatocytes by alloxan. Biochem Int 9: 595-602

37. Meglasson MD, Burch PT, Berner DK, Najafi H, Matschinsky FM (1986) Identification of glucokinase as an alloxan-sensitive glucose sensor of the pancreatic beta-cell. Diabetes 35: 1163-1173

38. Lenzen S, Tiedge M, Panten U (1987) Glucokinase in pancreatic B-cells and its inhibition by alloxan. Acta Endocrinol (Copenh) 115: 21-29

39. Bromme HJ, Weinandy R, Peschke D, Peschke E (2001) Simultaneous quantitative determination of alloxan, GSH and GSSG by HPlc. Estimation of the frequency of redox cycling between alloxan and dialuric acid. Horm Metab Res 33: 106-109 
40. Jörns A, Tiedge M, Lenzen S, Munday R (1999) Effect of superoxide dismutase, catalase, chelating agents, and free radical scavengers on the toxicity of alloxan to isolated pancreatic islets in vitro. Free Radic Biol Med 26: 1300-1304

41. Bloch KO, Zemel R, Bloch OV, Grief H, Vardi P (2000) Streptozotocin and alloxan-based selection improves toxin resistance of insulin-producing RINm cells. Int J Exp Diabetes Res 1: 211-219

42. Schnedl WJ, Ferber S, Johnson JH, Newgard CB (1994) STZ transport and cytotoxicity. Specific enhancement in GLUT2- expressing cells. Diabetes 43: 1326-1333
43. Mathews CE, Leiter EH (1999) Resistance of ALR/Lt islets to free radical-mediated diabetogenic stress is inherited as a dominant trait. Diabetes 48: 2189-2196

44. Mathews CE, Leiter EH (1999) Constitutive differences in antioxidant defense status distinguish alloxan-resistant and alloxan-susceptible mice. Free Radic Biol Med 27: 449-455 